\title{
Physiological and physico-chemical characterization of dietary fibre from the green seaweed Ulva fasciata Delile
}

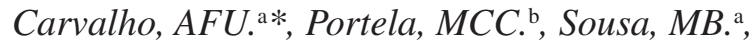

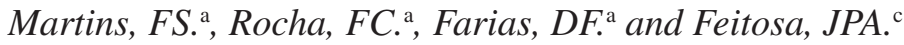 \\ aDepartamento de Biologia, Universidade Federal do Ceará - UFC, \\ Av. Mister Hull, s/n, Campus do Pici, CEP 60455-970, Fortaleza, CE, Brazil \\ bDepartamento de Tecnologia de Alimentos, Universidade Federal do Ceará - UFC, \\ Av. Mister Hull, s/n, Campus do Pici, CEP 60455-970, Fortaleza, CE, Brazil \\ 'Departamento de Química Orgânica e Inorgânica, Universidade Federal do Ceará - UFC, \\ Av. Mister Hull, s/n, Campus do Pici, CEP 60455-970, Fortaleza, CE, Brazil \\ *e-mail: aurano@ufc.br \\ Received May 14, 2008 - Accepted August 20, 2008 - Distributed August 31, 2009
}

\begin{abstract}
This work aims to assess the potential of the green seaweed Ulva fasciata Delile as an alternative source of dietary fibre (DF). Total DF content was determined, some of its physico-chemical properties described and the physiological effects of $U$. fasciata meal on rats fed a hypercholesterolemic diet were investigated. $U$. fasciata may be considered a potential alternative source of DF with a total content of about $400 \mathrm{~g} \cdot \mathrm{kg}^{-1}$ (dry basis) and interesting physico-chemical properties: water retention capacity of $8.74 \mathrm{~g} /$ water. $^{-1}$ dry sample (seaweed meal) and 0.90 (seaweed carbohydrate extract), lipid adsorption capacity of $4.52 \mathrm{~g} / \mathrm{oil}^{-1} \mathrm{~g}^{-1}$ dry sample (seaweed meal) and 5.70 (seaweed carbohydrate extract), intrinsic viscosity of $2.4 \mathrm{dl} . \mathrm{g}^{-1}$ (seaweed carbohydrate extract) and cation exchange capacity of $3.51 \mathrm{Eq} \cdot \mathrm{kg}^{-1}$ (seaweed carbohydrate extract). The diet containing seaweed meal was able to keep rats' total cholesterol (TC) down without causing any undesirable increase in LDL-C fraction. No evidence of toxic and/or antinutritional components in the seaweed meal was detected. Rats showed a fecal volume much greater $(13 \mathrm{~g})$ than that fed on cellulose diet $(7 \mathrm{~g})(\mathrm{p}<0.05)$. These properties confer on the seaweed the potential to be used in food technology for the acquisition of low-calorie food and might be important in body weight control, reduction of blood TC and LDL-C as well as in prevention of gastrointestinal diseases.
\end{abstract}

Keywords: Ulva fasciata, dietary fibre, seaweeds, physiological and physico-chemical characteristics.

\section{Caracterização fisiológica e físico-química da fibra alimentar da macroalga marinha verde Ulva fasciata Delile}

\begin{abstract}
Resumo
Este trabalho objetivou avaliar o potencial da alga marinha verde Ulva fasciata Delile como fonte alternativa de fibra alimentar. Foram realizadas a determinação do teor de fibra alimentar total e a descrição de algumas propriedades físico-químicas, e os efeitos fisiológicos da farinha da alga seca sobre ratos alimentados com dieta hipercolesterolemizante foram investigados. Esta alga pode ser considerada uma fonte alternativa potencial de fibra com

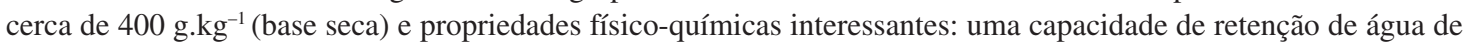
8,74 g/água. $\mathrm{g}^{-1}$ de amostra seca (farinha de alga) e 0,90 (extrato de carboidratos), uma capacidade de adsorção de lipídeos de 4,52 g/óleo.g ${ }^{-1}$ de amostra seca (farinha de alga) e 5,70 (extrato de carboidratos), uma viscosidade intrínseca de 2,4 dl.g-1 (extrato de carboidrato da alga) e capacidade de troca iônica de 3,51 Eq. $\mathrm{kg}^{-1}$ (extrato de carboidrato). A dieta contendo farinha de alga foi capaz de manter baixos os níveis de colesterol total de ratos sem causar aumento indesejável na fração LDL-C. Nenhuma evidência de componentes tóxicos e/ou antinutricionais na farinha de alga foi encontrada. Os ratos mostraram um volume fecal maior ( $13 \mathrm{~g}$ ) do que aqueles alimentados com dieta contendo celulose como fonte de fibra $(7 \mathrm{~g})(\mathrm{p}<0,05)$. Essas propriedades conferem a alga o potencial de ser utilizada na tecnologia de alimentos para a aquisição de alimentos de baixas calorias, podendo ser importante para o controle do peso corporal, redução do colesterol sanguíneo total e da fração LDL-C, como também na prevenção de doenças gastrintestinais.
\end{abstract}

Palavras-chave: Ulva fasciata, fibra alimentar, macroalgas, caracterização fisiológica e físico-química. 


\section{Introduction}

The nutritive value of seaweeds is mainly due to their protein, polysaccharide, mineral and vitamin contents. The high levels of non-digestible polysaccharide in their cell wall make seaweeds a rich source of dietary fibre (330-500 g.kg ${ }^{-1}$, dry weight basis) (Rupérez and SauraCalixto, 2001). There are, however, different types of dietary fibre (DF) in each seaweed group. Thus, brown seaweeds show alginates, fucans and laminarans as soluble DF, while the red ones have the galactans agar and carragenin. The green seaweeds, the object of study of this work, show the soluble ulvans and an insoluble fraction, which does not differ much in the different seaweed groups. It consists mainly of cellulose. One exception for that is the red seaweed nori, which contains insoluble mannans and xylans (Rupérez and Saura-Calixto, 2001).

Inadequate level of DF in the diet has been implicated in coronary heart disease (CHD), high blood pressure, obesity, hypercholesterolemia, hyperlipidemia, gallstones, varicose veins, diabetes, constipation and diverticulitis (MacPherson, 1993). A per capita daily intake of $30 \mathrm{~g}$ of DF or $12 \mathrm{~g}$ of DF $1,000 \mathrm{kcal}^{-1}$ per day is considered desirable, to be obtained from as varied sources as possible with about one-third being soluble fibre. Fruits, vegetables, oats, plant gums and mucilages, seaweed and microbial polysaccharides are important sources of soluble DF, while cereal sources provide a major part of insoluble DF (Potty, 1996). The role of DF on the reduction of CHD risk involves the physico-chemical and biochemical properties of fibre, such as viscosity, water retention, bile acids binding, cation exchange, producing large fecal volume capacities and fermentability (Dvir et al., 2000).

Since ancient times in Asia seaweeds have been consumed in great quantities as food but in the western world seaweed species have been used mainly as food additives (Glickman, 1987). However, there has been an increasing interest in edible seaweeds in Europe and Latin America (Fleurence, 1991; Acleto, 1996; Aguilera-Morales et al., 2005). This work aims to assess the potential of the green seaweed Ulva fasciata Delile, abundant on the Brazilian coast, as an alternative source of DF. Thus its total DF content was determined, some of its physico-chemical properties described and the physiological effects of $U$. fasciata meal on rats fed a hypercholesterolemic diet were investigated.

\section{Material and Methods}

\subsection{Seaweed samples}

Samples of the whole green seaweed $U$. fasciata were collected during low tide from the northeastern coast of Brazil (Pacheco and Flexeiras beaches, State of Ceará). They were identified and kept in plastic bags at $-10{ }^{\circ} \mathrm{C}$ until used (Taylor, 1960; Joly, 1965; Wynne, Bold, 1978). Algal samples were washed thoroughly with tap and distilled water, dried in oven at $37{ }^{\circ} \mathrm{C}$, ground in a coffee mill and seived through a granulometric mesh of $0.42 \mathrm{~mm}$.

\subsection{Carbohydrate extraction}

$2.5 \mathrm{~L}$ of distilled water was heated up to $80^{\circ} \mathrm{C}$ and $50 \mathrm{~g}$ of seaweed meal was added and kept under agitation for 30 minutes. After that, the mixture was filtered under vacuum three times. The extract was then frozen at $-10{ }^{\circ} \mathrm{C}$ and freeze-dried by high vacuum dehydration.

\subsection{Determination of proximal composition}

All chemical analyses were done at least in duplicate on moisture-free samples. For dry matter determination about $2 \mathrm{~g}$ of the seaweed was placed into a pre-weighed glass tube previously dried in oven at $110{ }^{\circ} \mathrm{C}$ and allowed to dry under the same conditions for 24 hours. The sample was then weighed and this procedure repeated until constant weight was obtained. A manual colorimetric procedure for measuring ammonium nitrogen in Kjeldahl digests was used for the determination of total nitrogen and protein content, which was calculated using a nitrogen conversion factor of 6.25 (Baethgen and Alley, 1989). Fat content was determined by taking a sample weighing $3 \mathrm{~g}$ in filter paper sacks and placing it into the Soxhlet system A.O.A.C. (1997). The extraction was continuous over 8 hours using n-hexane as solvent in the proportion of 1:50 (w:v). Total ash was determined by calcination in oven at $550{ }^{\circ} \mathrm{C}$ until constant weight A.O.A.C. (1997). Total DF content was determined according to the A.O.A.C. method with some modifications (Prosky et al., 1988; Lahaye, 1991). Carbohydrate content was determined by calculating the percentile difference from all the other constituents.

\subsection{Physico-chemical characterization of seaweed carbohydrates}

\subsubsection{Water Retention Capacity (WRC)}

WRC was determined according to the reported methodology (Rupérez and Saura-Calixto, 2001). 30 mL of distilled water was added to the sample $(1 \mathrm{~g})$ in a centrifuge tube. The sample was agitated and left at room temperature for 1 hour. Then, the mixture was centrifuged $(12,000 \times \mathrm{g}, 20$ minutes), the supernatant discarded and the residue weighed. The WRC was expressed as $\mathrm{g}$ of water. $\mathrm{g}^{-1}$ dry sample.

\subsubsection{Lipid Adsorption Capacity (LAC)}

LAC was determined following Caprez and Neaukom's (1986) methodology, where samples (3 g) were added to sunflower oil (18 mL), left overnight at room temperature $\left(25^{\circ} \mathrm{C}\right)$, centrifuged at $1500 \times \mathrm{g}$ for 10 minutes and the supernatant disposed. LAC was expressed as grams of oil. $\mathrm{g}^{-1}$ dry sample.

\subsubsection{Intrinsic viscosity}

The intrinsic viscosity of the carbohydrate extract of U. fasciata re-suspended in $0.1 \mathrm{M} \mathrm{NaCl}$ at $37{ }^{\circ} \mathrm{C}$ was 
determined according to drainage time in an Ubbelohde viscosimeter.

\subsubsection{Cation Exchange Capacity (CEC)}

CEC was determined according to reported methodologies (Bobin-Dubigeon et al., 1997). The functional cation groups of samples $(300 \mathrm{mg}$ ) were initially converted to their acidic forms, by adding $50 \mathrm{~mL}$ of $0.01 \mathrm{~N} \mathrm{HCl}$, storing overnight at $4{ }^{\circ} \mathrm{C}$ and centrifuged at $12,000 \times \mathrm{g}$ for 20 minutes. The precipitate was then washed with deionized water, and centrifuged once more at $12,000 \times \mathrm{g}$ for 20 minutes. After centrifugation, the supernatant was titrated with $0.02 \mathrm{~N} \mathrm{KOH}$ and the results expressed as Eq. $\mathrm{kg}^{-1}$ of the dry sample.

\subsection{Thiamin binding assay}

The capacity of $U$. fasciata fibre to bind thiamin was determined by using two samples $(200 \mathrm{mg}$ ) of carbohydrate extract placed in centrifuge tubes to which $20 \mathrm{~mL}$ of $1 \mathrm{mM}$ thiamin hydrochloride in $66 \mathrm{mM}$ phosphate buffer, $\mathrm{pH} 6.0$ was added. This mixture was incubated at $37{ }^{\circ} \mathrm{C}$ for 1 hour under agitation, followed by centrifugation at $9,000 \times \mathrm{g}$ (Jouan GR-22, France) for 10 minutes. Supernatant was removed and taken for spectrophotometrical reading at $267 \mathrm{~nm}$, with a final $\mathrm{pH}$ of 6.0 (Genesys uv10, thermospectronic, United States). The result was considered negative (no capacity to bind thiamin) when the absorption value of thiamin solution was not affected after incubation with the carbohydrate extract (Bobin-Dubigeon et al., 1997).

\subsection{Animals and feeding experiment}

A feeding trial was conducted with Wistar male rats weighing 190-200 g, obtained from the animal facilities of the Federal University of Ceará. They were fed ad libitum on a commercial diet (Dispa Indústria de ração S.A., Messejana, Brazil) for 5 days as an adaptation period to powdered diets and were selected according to food consumption and body weight. The rats were divided into 3 groups of 6 rats each. The body weight range within the group was $10 \mathrm{~g}$ and between groups, was $5 \mathrm{~g}$. The rats were individually housed in acrylic cages with wire-mesh floors in a temperature-controlled room (23-25 $\left.{ }^{\circ} \mathrm{C}\right)$, which was kept on a 12 hours artificial lighting cycle. Control and experimental diets (Table 1) containing saturated fat and cholesterol at 5 g. $\mathrm{kg}^{-1}$ diet were given for 30 days. Food refusals were weighed daily and body-weight measured every 2 days. Four blood collections after 16 hours fasting were carried out throughout the experiment by sectioning $2 \mathrm{~mm}$ of rat tail: one collection made before the feeding experiment (day 0), one on day 10 , the other on day 20 and the last one on day 30 . At the end of the feeding period, rats were fasted for 15-16 hours, killed by halothane overdose and the abdominal cavity opened. The digestive organs (stomach, small and large intestines, pancreas and liver) were quickly removed, freeze-dried and weighed. The carcasses were also freeze-dried to have their protein and fat contents determined.

\subsection{Determination of blood lipid profile}

Blood samples were taken after 16 hours fasting in heparinized tubes $(10 \mu \mathrm{L})$, before rats were fed with experimental diets $\left(\mathrm{T}_{0}\right)$, on day $10\left(\mathrm{~T}_{10}\right)$, on day $20\left(\mathrm{~T}_{20}\right)$ and on the last day of the experiment $\left(\mathrm{T}_{30}\right)$. Levels of total cholesterol (TC), high density lipoproteins (HDL-C) and triglycerides (TG) were estimated by using kits of enzymatic assay (Labtest Diagnóstica S.A., São Paulo). Levels of very-low density (VLDL-C) and low-density lipoproteins (LDL-C) were calculated by using the appropriate formulae (Allain et al., 1974; Mahan and Escott-Stump, 1996).

\subsection{Statistical analyses}

Mann-Whitney/Wilcoxon hypothesis tests were run to compare median values of blood lipoprotein and triglycerides since mean values were not representative of a central tendency of the data. This test is based upon the ordering of median values from two populations for calculating the estimate point, using a confidence interval of $95 \%$ (Hollander and Wolfe, 1999). For all the other determinations, a Student $\mathrm{t}$-test was used to compare mean values $(\mathrm{p}<0.05)$.

\section{Results and Discussion}

\subsection{Proximal composition and total dietary fibre of $U$. fasciata meal}

The results of proximal analysis of seaweed meal are described in Table 2. The high total DF content

Table 1. Diet composition ( $\mathrm{g} \cdot \mathrm{kg}^{-1}$ ) of control (cellulose) and test group (seaweed meal).

\begin{tabular}{lcc}
\hline \multicolumn{1}{c}{ Ingredients } & Seaweed & Cellulose \\
\hline Corn starch & 282.94 & 387.5 \\
Glucose & 144.97 & 145.27 \\
Coconut oil & 139.63 & 140.43 \\
Cholesterol & 4.84 & 4.84 \\
Egg white & 88.76 & 128.27 \\
Vitamin mixture & 48.38 & 48.42 \\
Mineral mixture & 48.38 & 48.42 \\
Seaweed meal & 242.10 & - \\
Celulose & - & 96.85 \\
Total mass $(\mathrm{g})$ & 1000.00 & 1000.00 \\
Caloric density $\left(\mathrm{kcal.g}{ }^{-1}\right)$ & 3.88 & 3.91 \\
\hline
\end{tabular}

Table 2. Proximal composition of Ulva fasciata meal.

\begin{tabular}{lc}
\hline Constituents & g.kg $^{-1}$ dry basis \\
\hline Protein & $122.4 \pm 15.7$ \\
Lipid & $2.10 \pm 0.1$ \\
Ash & $127.9 \pm 0.6$ \\
Fibre & $399.2 \pm 13.0$ \\
Carbohydrate & $348.3 \pm 1.9$ \\
\hline
\end{tabular}

Values are means \pm standard deviation for at least duplicate. 
(399.2 g. $\mathrm{kg}^{-1}$, dry basis) of this seaweed species confirms those described for other species from the same genus, such as U. lactuca (381.0 g. $\left.\mathrm{kg}^{-1}\right)$ (Lahaye, 1991). In the present work the two fractions (soluble and insoluble) were not separated due to some technical difficulties such as funnels clogging during the separation procedure. Nevertheless it is already known that seaweeds have higher levels of soluble than insoluble fibre, the opposite of what usually happens in land plants (Anderson and Bridges, 1988). This information taken together with those on the peculiar properties of seaweed polysaccharides have encouraged works on the potentiality of seaweeds as a source of DF, with interesting physiological and/or technological properties (Bobin-Dubigeon et al., 1997; Lahaye and Kaeffer, 1997).

\subsection{Carbohydrate extraction}

The yield of carbohydrate extract was as low as $100 \mathrm{~g} . \mathrm{L}^{-1}$ in relation to total seaweed dry mass $(\mathrm{n}=23$ extraction procedures). Nevertheless, this extraction procedure was maintained considering that a very small amount would be sufficient for physico-chemical characterization assays.

The analysis of seaweed carbohydrate extract composition showed that, even after high vacuum dehydration, the moisture value was 143.8 g.L $\mathrm{L}^{-1}$. Total DF concentration was $400 \mathrm{~g} . \mathrm{kg}^{-1}$, the same concentration found in crude meal. Nevertheless, due to low yield in carbohydrate extraction DF could not show more concentrated values.

\subsection{Physico-chemical characterization of carbohydrate extract}

\subsubsection{Water retention capacity}

The results of this analysis (Table 3) showed that the carbohydrate extract of the seaweed showed WRC of $0.90 \pm 0.09 \mathrm{~g} /$ water. $^{-1}$ dry sample while that of $80 \%$ deacetylated chitosan (Polymar Ciência e Saúde SA, Fortaleza, Brazil) determined for comparative purposes, was of $4.87 \pm 0.07 \mathrm{~g} /$ water. $^{-1}$ dry sample. WRC for carbohydrate extract of $U$. fasciata was very low, considering that it is known that seaweeds of this genus have both soluble and insoluble DF. Several authors are contradictory when discussing this property. Some say that the capacity of water retention is attributed to insoluble fibre, whereas others attribute it to the high content of uronic acids, components of soluble fraction of DF (Femenia et al., 1997; Rupérez and Saura-Calixto, 2001). Nevertheless, there is a consensus that this property depends upon the experimental conditions, such as temperature, $\mathrm{pH}$, time, centrifugation circumstances, as well as upon sample preparation and particle size (Michel et al., 1988; Suzuki et al., 1996; Femenia et al., 1997). In the case of the carbohydrate extract of $U$. fasciata, the factor that should have major influence was the temperature during the extraction procedure, which reached as high as $90{ }^{\circ} \mathrm{C}$. Data from an experiment with cauliflower have shown that the WRC was reduced significantly from 12.8 to 5.7 g. $\mathrm{g}^{-1}$ when a temperature of over $75^{\circ} \mathrm{C}$ for dehydration was used (Femenia et al., 1997). The author emphasised the importance that the matrix structure has upon the polysaccharide functional properties. Besides, in this work it has been observed that the WRC for seaweed meal, with particle size of $0.42 \mathrm{~mm}$, showed WRC well above that of its carbohydrate extract $\left(8.74 \mathrm{~g} . \mathrm{g}^{-1}\right.$ dry sample), a value similar to those described for other seaweed species, varying from 5 to $11 \mathrm{~g} \cdot \mathrm{g}^{-1}$ dry sample. This fact confirms the importance the heat treatment might have upon the functional properties of the components (Rupérez and Saura-Calixto, 2001).

WRC for chitosan was higher than that for the seaweed extract; chitosan particle size was quite smaller (data not shown) and the $\mathrm{pH}$ was alkaline (7.7). Data in literature reveal that the lower the $\mathrm{pH}$ of solution containing the DF, the lower the WRC. At stomach $\mathrm{pH}$, this property is reduced about fivefold, when compared to pH 6.4 (Suzuki et al., 1996). The suspension of the seaweed meal showed a $\mathrm{pH}$ of 5.4, slightly acid, lower than $\mathrm{pH}$ of intestine. Studies with seaweeds in Spain at about the same $\mathrm{pH}$ have shown that WRC varied from 5 to 11 g.g ${ }^{-1}$ dry sample (Rupérez and Saura-Calixto, 2001).

Regarding food industry interests, high values of WRC for DF are important when adjustments in texture of meat products and salad dressings are needed for

Table 3. Physicochemical characterization of samples of Ulva fasciata meal, U. fasciata carbohydrate extract and chitosan.

\begin{tabular}{lccc}
\hline \multicolumn{1}{c}{$\begin{array}{c}\text { Physico-chemical } \\
\text { properties }\end{array}$} & $\begin{array}{c}\text { Seaweed } \\
\text { meal }\end{array}$ & $\begin{array}{c}\text { Seaweed carbohydrate } \\
\text { extract }\end{array}$ & Chitosan \\
\hline $\begin{array}{l}\text { Water retention capacity } \\
\left(\mathrm{g} / \mathrm{H}_{2} \mathrm{O}_{\mathrm{g}} \mathrm{g}^{-1} \text { dry sample }\right)\end{array}$ & $8.74 \pm 0.30$ & $0.90 \pm 0.09$ & $4.87 \pm 0.07$ \\
$\begin{array}{l}\text { Lipid Adsorption Capacity } \\
\left(\mathrm{g} / \mathrm{oil}^{-1} \mathrm{~g}^{-1} \text { dry sample }\right)\end{array}$ & $4.52 \pm 0.27$ & $5.70 \pm 0.08$ & $2.41 \pm 0.06$ \\
Intrinsic viscosity $\left(\mathrm{dl} . \mathrm{g}^{-1}\right)$ & $\mathrm{ND}$ & 2.4 & $\mathrm{ND}$ \\
Cation Exchange Capacity & $\mathrm{ND}$ & $3.51 \pm 0.08$ & $9.72 \pm 0.09$ \\
$\left(\right.$ Eq.kg $\left.{ }^{-1}\right)$ & & & $\mathrm{ND}$ \\
Fecal volume $(\mathrm{g})$ & $12.73 \pm 4.27$ & $\mathrm{ND}$ & $\mathrm{ND}$ \\
Thiamin binding & $\mathrm{ND}$ & Negative & \\
\hline
\end{tabular}

ND: Not determined. Values are means \pm standard deviation of at least duplicates. 
producing low calorie foods. Low values, however, are important when interest lies upon sugar substitutes in low calorie food products such as extruded snacks, corn flakes, cookies and crackers (Matz, 1996). A DF with high WRC values may also bring physiological benefits since it promotes large fecal volume and consequently reduces transit time in gut. This is a desirable characteristic to prevent constipation, diverticulitis and maybe colon cancer (Mahan and Escott-Stump, 1996; Matz, 1996).

\subsubsection{Lipid adsorption capacity}

The result of this analysis was compared to that obtained with chitosan which usually shows a high lipid adsorption capacity (Craveiro et al., 1999; Nauss et al., 1983). The seaweed carbohydrate extract had approximately two-fold the capacity of chitosan. In the present work the value for chitosan was somewhat surprising since other workers have shown that the amount of lipid adsorbed by chitosan is around 8-10 times its weight (Craveiro et al., 1999). In this work, following an in vitro methodology, the LAC for chitosan was only $2.41 \mathrm{~g} . \mathrm{g}^{-1}$ whilst that for seaweed carbohydrate extract was 5.70. In fact, the LAC of chitosan is influenced by many variables such as ionic strength and pH (Nauss et al., 1983). The high LAC is an important characteristic when physiological effects of DF are concerned since this capacity may interfere with dietary lipid absorption in the gut. This property is therefore very important for helping to control body weight and abnormal blood lipid profiles (Bobin-Dubigeon et al., 1997; Jimenez-Escrig and Sanchez-Muniz, 2000).

\subsubsection{Intrinsic viscosity}

The intrinsic viscosity of $U$. fasciata carbohydrate extract at $37{ }^{\circ} \mathrm{C}$ (simulating body temperature) was $0.24 \mathrm{dl} . \mathrm{g}^{-1}$, much lower than those cited by Lahaye and Jegou (1993) for Ulva sp. (0.4-1.5 dl.g $\left.\mathrm{g}^{-1}\right)$. This result was coherent with the fact that Ulva sp only forms very weak gels at the presence of boric acid and calcium at $\mathrm{pH}$ 7.5. Besides, the values obtained previously were determined in samples of purified ulvans and not in crude carbohydrate extracts. The lower value obtained may have been due to some influence of the thermal processing that $U$. fasciata samples went through during carbohydrate extraction. In this case the glycosidic linkages may have been broken and as a consequence there was a redistribution of high molecular mass soluble components to smaller fragments, reducing viscosity (Lahaye and Jegou, 1993; Nyman, 1995). In addition, it is known that ulvans obtained from different Ulva species show low viscosity and even from a single species, polymers with different molecular mass can be obtained (Lahaye and Robic, 2007). Thus, it may be possible that the extraction procedure used in the present work could have preferentially extracted low molecular mass polymers and so justify the lower viscosity values in relation to other ulvans.
Considering technological applications, a high viscosity fibre would be very important for producing foods classified as light products because it would increase viscosity of the liquid phase aiming to imitate viscosity and sensorial impressions of oil (Matz, 1996). In this case, the carbohydrate extract of $U$. fasciata cannot be classified as a hydrocolloid gum. In what concerns physiological benefits, viscous fibres promote local responses along the gastrointestinal tract. These responses are associated with several important systemic effects. At the stomach, the viscosity of soluble fibre slows gastric emptying, improving digestion and absorption and promotes saciety. Besides, a high viscosity fibre hinders nutrient absorption because it slows down the enzymatic process of digestion and micelle formation and may reduce lipid absorption, resulting in low body weight gain (Davidson and Mcdonald, 1998; Dvir et al., 2000).

\subsubsection{Cation exchange capacity}

The results (Table 3) showed that seaweed carbohydrate extract had higher values than that described for Ulva sp meal and three-fold lower than that for chitosan (Bobin-Dubigeon et al., 1997). Some authors reported that ulvans show high CEC due to high content of sulfate and uronic acid. Thus, the value reported here gives support to those findings. The values found for both the seaweed extract and chitosan were significantly higher than those described for fibre from land plants, which are generally in the range of 1-2.4 Eq. $\mathrm{kg}^{-1}$ (Michel and Macfarlane, 1996; Rupérez and Saura-Calixto, 2001). The values for chitosan can be explained by its high charge density, one positive charge for each glycosamine unit (Craveiro et al., 1999). The main advantage of high CEC values for humans is the therapeutic role in reducing blood cholesterol. DF with high CEC values can usually unstabilize and disintegrate the micelles by forming complex fibre/micelles, which act as barriers for diffusion or absorption of micelles. Thus, lipids and cholesterol cannot be efficiently absorbed and utilised, resulting in reduction of blood cholesterol (Chau and Cheung, 1999).

\subsection{Thiamin binding}

The seaweed extract was not able to bind thiamin. This is a property that supports the recommendation of this seaweed as a DF source. One factor that may explain the failure of $U$. fasciata fibre to bind thiamin is its low WRC value (Table 3). Nevertheless, it has been described that the capacity to bind thiamin is not clearly associated with WRC. It has been reported that the correlation coefficient between thiamin binding capacity and WRC is quite low ( $r=0.501)$ (Suzuki et al., 1996). On the other hand, some authors have reported a positive correlation between losses of water-soluble vitamins, e.g., ascorbic acid, and DF content in several sources (Omaye et al., 1982; Khokhar and Kapoor, 1990). In fact, very little is known about the effects of DF upon vitamin bioavail- 
ability (Khokhar and Kapoor, 1990; Sizer and Whitney, 2007)

\subsection{Feeding trial}

The results of the feeding trial with seaweed meal showed (Table 4) that there was significant difference $(\mathrm{p}<0.05)$ between the intake of rats fed diet containing cellulose as a source of dietary fibre (ca $460 \mathrm{~g}$ ) and those fed on diet containing seaweed meal (ca $530 \mathrm{~g}$ ). In fact the seaweed group had an intake slightly higher than the control group. This may bring evidence that there were no toxic or antinutritional components in the seaweed meal since it is known that when rats are fed a diet, which is poorly balanced or contains deleterious components, their intake is reduced as part of a defense mechanism (Bardocz et al., 1996). Thus, it is important to emphasise that the animals fed with diet containing seaweed meal showed good acceptance of diet, coming to ingest an amount slightly higher than those fed with the control diet. As to the fecal volume, the results showed that the group having seaweed meal showed a fecal volume much greater (ca $13 \mathrm{~g}$ ) than that fed on cellulose diet (ca $7 \mathrm{~g})$, actually twice as much $(\mathrm{p}<0.05)$.
The increase in fecal volume is said to be due mainly to the insoluble fraction of fibre (Mahan and Escott-Stump, 1996). Nevertheless, when this kind of DF is present in diet, along with the soluble fraction, there seems to occur a better softening of feces and increased volume due to binding of water and ions in intestinal lumen. Seaweeds have soluble and insoluble fibres in their chemical composition, being the soluble proportion greater than the insoluble one. Some authors associate the increase in fecal volume to the WRC and to the impact of microbial proliferation, since fibre is the only dietary component, which can significantly increase fecal weight, supplying substrate for colon microbiote (Lahaye, 1991; Franco, 1992). This supports the result of increased fecal weight for rats fed on seaweed meal, since $U$. fasciata shows a high WRC (Table 3).

As to body weight gain, the results showed that there was no significant difference between the two groups of animals ( $p>0.05)$. This may be indicative that there was no toxic/or antinutritional effects caused by seaweed meal. Other evidence that points to lack of toxicity is given by the relative weight of digestive organs. It is recognised that when a diet contains toxic components,

Table 4. Nutritional parameters of rats fed during 30 days with isocaloric and isonitrogenous diets, containing seaweed meal or cellulose as source of dietary fibre.

\begin{tabular}{lcc}
\hline & $\begin{array}{c}\text { Control diet } \\
\text { (Cellulose) }\end{array}$ & $\begin{array}{c}\text { Experimental diet } \\
\text { (Seaweed meal) }\end{array}$ \\
\hline Dietary intake (g) & $457.96 \pm 66.44^{\mathrm{a}}$ & $530.51 \pm 33.62^{\mathrm{b}}$ \\
Fecal volume dry weight $(\mathrm{g})$ & $6.98 \pm 2.41^{\mathrm{a}}$ & $12.73 \pm 4.27^{\mathrm{b}}$ \\
Body weight gain (g) & $110.52 \pm 15.70^{\mathrm{a}}$ & $113.82 \pm 17.20^{\mathrm{a}}$ \\
Organs (g.kg-1 body weight) & & \\
Liver & $40.0 \pm 4.0^{\mathrm{a}}$ & $42.0 \pm 3.0^{\mathrm{a}}$ \\
Pancreas & $2.30 \pm 0.7^{\mathrm{a}}$ & $3.1 \pm 0.1^{\mathrm{a}}$ \\
Stomach & $6.90 \pm 1.0^{\mathrm{a}}$ & $8.0 \pm 1.0^{\mathrm{a}}$ \\
Small intestine & $28.0 \pm 3.0^{\mathrm{a}}$ & $26.0 \pm 3.0^{\mathrm{a}}$ \\
Large intestine & $8.2 \pm 0.2^{\mathrm{a}}$ & $12.0 \pm 0.7^{\mathrm{b}}$ \\
\hline
\end{tabular}

Values are means \pm standard deviation $(n=6)$. Different superscrits on the same rows represent values significantly different $(\mathrm{p}<0.05)$.

Table 5. Blood lipoproteins profile $\left(\mathrm{mg} \cdot \mathrm{dL}^{-1}\right)^{*}$ of Wistar rats fed with hypercholesterolemic diet contaning cellulose and seaweed meal (Ulva fasciata).

\begin{tabular}{|c|c|c|c|c|c|}
\hline & & $T_{0}$ & $\mathbf{T}_{10}$ & $\mathbf{T}_{20}$ & $\mathbf{T}_{30}$ \\
\hline \multirow[t]{4}{*}{ Cellulose } & $\mathrm{TC}$ & $84.24^{\mathrm{a}}$ & $102.12^{b}$ & $105.76^{\mathrm{b}}$ & $98.79^{\mathrm{b}}$ \\
\hline & HDL & $49.61^{\mathrm{a}}$ & $53.00^{\mathrm{a}}$ & $55.84^{\mathrm{ab}}$ & $64.03^{\mathrm{b}}$ \\
\hline & LDL & $15.36^{\mathrm{a}}$ & $27.14^{\mathrm{a}}$ & $15.89^{\mathrm{a}}$ & $5.74^{\mathrm{a}}$ \\
\hline & VLDL & $17.41^{\mathrm{a}}$ & $22.72^{\mathrm{a}}$ & $21.00^{\mathrm{a}}$ & $22.06^{\mathrm{a}}$ \\
\hline \multirow[t]{4}{*}{ Seaweed } & TC & $90.91^{\mathrm{a}}$ & $137.42^{\mathrm{b}}$ & $110.91^{\mathrm{ab}}$ & $108.03^{\mathrm{a}}$ \\
\hline & HDL & $53.96^{\mathrm{a}}$ & $50.39^{\mathrm{a}}$ & $44.74^{\mathrm{a}}$ & $46.82^{\mathrm{a}}$ \\
\hline & LDL & $19.94^{\mathrm{a}}$ & $30.99^{\mathrm{a}}$ & $23.20^{\mathrm{a}}$ & $18.73^{\mathrm{a}}$ \\
\hline & VLDL & $15.86^{\mathrm{a}}$ & $32.56^{\mathrm{b}}$ & $37.21^{\mathrm{b}}$ & $38.08^{\mathrm{b}}$ \\
\hline
\end{tabular}

*Values are medians $(n=6)$. Different superscripts in the same row represent values significantly different (Wilcoxon/Mann-Whitney, $\mathrm{p}<0.05$ ). 
their detection can occur through observation of alterations in relative organ weights. These alterations may be either seen as increased organ weight or organ involution (Bardocz et al., 1996). The results of the analysis of relative organ weights showed that there was no significant difference $(p>0.05)$ between the groups in what concerns liver, pancreas, stomach and small intestine. There was, however, a significant increase $(\mathrm{p}<0.05)$ in relative weight of large intestine of rats fed the seaweed meal diet. Several works on different types of non-digestible polysaccharides have shown effects upon intestinal metabolism. Rats fed on different polysaccharides had increased cecum and colon and these increases were due to tissue hypertrophy in response to increased fecal volume. Likewise rats fed with seaweed fibre did not show any reduction in food intake or food efficiency, but had significant increase in cecum weight (Wyatt et al., 1988; Rupérez and Saura-Calixto, 2001). Thus, it appears that the increase in the large intestine seen in this work may be an adaptative response of animals to increased fecal volume.

\subsection{Blood lipid profile}

The data of blood TC and lipoproteins showed extreme values among rats, causing the mean not to be representative of a central tendency. Thus median values were used for statistical tests. The results (Table 5) showed that the rats fed on diet containing cellulose as a source of DF had a significant increase $(p<0.05)$ in total blood cholesterol at day 10 of the experiment, and this value was kept constant throughout the whole experiment. As to the seaweed-fed rats, TC levels increased significantly at day 10 , but from day 20 to the end of the experiment, they reduced to previous values $\left(\mathrm{T}_{0}\right)$. It is known that TC levels may be increased by high intake of calories, saturated fat and cholesterol. The following may reduce these levels: body weight loss, replacement of polyunsaturated for saturated fatty acid and increase in DF intake, specially the soluble fraction (Anderson, 1987). In this work the diet intake did not show any correlation with total blood cholesterol since seaweed-fed rats had intake significantly higher (ca $530 \mathrm{~g}$ ) than those fed cellulose (ca $460 \mathrm{~g}$ ) and even so, they did not show any trend to keep TC at higher levels. Seaweed meal was able to prevent the hypercholesterolemic effect of a diet rich in saturated fat and cholesterol, contrary to what happened with the cellulose diet. This efficiency in keeping TC practically constant throughout the experiment may be explained by the fact that seaweeds are good sources of dietary soluble fibre. Seaweeds are particularly rich in DF, their concentration ranging from 327.0 to 746.0 g. kg-1 (dry basis), and the greatest part constitutes soluble fibre (516.0 to $850.0 \mathrm{~g} . \mathrm{kg}^{-1}$ ), which is the fraction responsible for the beneficial physiological effects (Lahaye, 1991). It has been shown that the species U. lactuca, has $213 \mathrm{~g} \mathrm{~kg}^{-1}$ of soluble fibre and $168 \mathrm{~g} \cdot \mathrm{kg}^{-1}$ of insoluble type, making a total content of $381 \mathrm{~g} . \mathrm{kg}^{-1}$, a value similar to the one found for $U$. fasciata (Lahaye,
1991). It is therefore indicative that the soluble fraction of $U$. fasciata fibre may also be responsible for the hypocholesterolemic effect observed in rats. A study on chemical and physico-chemical characteristics of $U$. lactuca showed that the soluble fraction consists of sulfated xylorhamnoglycuronan and the insoluble fraction essentially of glucans (Lahaye and Jegou, 1993).

The results of blood HDL-C, LDL-C and VLDL-C analyses (Table 5) showed that the hypercholesterolemic effect of the control diet could not be clearly detected in the different fractions of cholesterol as it was in TC. The only fraction that showed a trend to increase was HDL-C. Nevertheless the increase occurred only at the very end of the experiment and so could not explain the increase in TC over the experiment. As to the group fed on seaweed containing diet, the different fractions of cholesterol did not show any alteration over the experiment except for VLDL-C, which had a significant increase $(\mathrm{p}<0.05)$ over the experiment. An explanation for this increase could be the fact that the seaweed-fed group ingested about $70 \mathrm{~g}$ more of diet and this might have implicated in higher levels of triglycerides and consequently of lipoprotein VLDL-C. This lipoprotein, however, has not been associated to atherogenicity processes as it occurs to LDL-C, which is the primary transporter of cholesterol in blood and it is the lipoprotein with greater association with the incidence of coronary heart diseases (Katch and McArdle, 1993; Mahan and Escott-Stump, 1996). Thus, the diet containing seaweed meal was able to keep TC levels down without causing any undesirable significant increase in LDL-C. The initial increase in TC (day 10) must have been due to small increases in more than one fraction of cholesterol. Nevertheless, these individual increases must have been so low that they could not be detected.

The mechanism underlying the hypocholesterolemic effect of soluble fibre is not completely understood, but it may be related to several properties characteristic of soluble fibre including viscosity, bile salt binding capacity and fermentability (Davidson and Mcdonald, 1998). Although the viscosity for the fibre of $U$ fasciata was low (Table 3), as well as its fermentability, it may be possible that both factors are involved in the hypocholesterolemic mechanism (Durand, 1997). In this work it was seen that the seaweed meal shows high LAC and this could at least in part explain the reduction in TC. The high capacity to bind lipids is an important characteristic when the physiological benefits of DF are concerned because it may interfere with the absorption of dietary fat. This property is thus of great importance for the control of body weight and dislipidemias (Bobin-Dubigeon, 1997; JimenezEscrig and Sanchez-Muniz, 2000). Nevertheless, more detailed studies on the composition of soluble fibre of each dietary source and the mechanism of action upon lipid metabolism are needed. In conclusion, the green seaweed $U$. fasciata may be considered a potential alternative source of DF with a total content of about $400.0 \mathrm{~g} \mathrm{~kg}^{-1}$ (dry basis) and interesting physico-chemical 
properties, which may be used in food technology for the acquisition of low-calorie food. It might be important in body weight control, reduction of blood TC and LDL-C as well as in the prevention of gastrointestinal diseases.

Acknowledgements - The authors are grateful to FUNCAP for an MSc scholarship to the student Masu Capistrano Camurça Portela.

\section{References}

ACLETO, CO. 1996. Algas marinas del Perú de importancia económica. Peru: Universidade Nacional Mayor de San Marcos. $106 \mathrm{p}$.

AGUILERA-MORALES, M., CASAS-VALDEZ, S., CARRILO-DOMÍNGUEZ, S., GONZÁLEZ-ACOSTA, B. and PÉREZ-GIL, F. 2005. Chemical composition and microbiological assays of marine algae Enteromorpha ssp. as a potential food source. Journal of Food Composition and Analysis, vol. 18, no. 1, p. 79-88

ALLAIN, CC., POON, LS., CHAN, SG., RICHMOND, W. and FU, PC. 1974. Enzymatic determination of total cholesterol. Clinical Chemistry, vol. 20, no. 4, p. 470-475.

ANDERSON, JW. and BRIDGES, SR. 1988. Dietary fibre content of selected foods. American Journal of Cardiology, vol. 60 , no. 12 , p. $17-22$.

ANDERSON, JW. 1987. Dietary fiber, lipids and atherosclerosis. American Journal of Cardiology, vol. 60, no. 12, p. 17-22.

Association of Official Analytical Chemists - AOAC. 1997. Official Methods of Analysis. 16 ed. Washington, DC. 1115 p.

BAETHGEN, WE. and ALLEY, MM. 1989. A manual colorimetric procedure for measuring ammonium nitrogen in soil and plant Kjeldahl digests. Communications in Soil Science and Plant Analysis, vol. 20, no. 9, p. 961-969.

BARDOCZ, S., GRANT, G.,PUSZTAI,A.,FRANKLIN,MF. and CARVALHO, AFFU. 1996. The effect of phytohaemagglutinin on the growth, body composition, and plasma insulin of the rat at different dietary concentrations. British Journal of Nutrition, vol. 76 , no. 4, p. 613-626

BOBIN-DUBIGEON, C. et al. 1997. Chemical composition, physico-chemical properties enzymatic inibition and fermentative characteristics of dietary fibers from edible seaweads. Science des Aliments, vol. 17, p. 619-639.

CAPREZ-AMADO, R. and NEAUKOM, H. 1986. Influence of different type of thermal treatment on the chemical composition and physical properties of wheat bran. Journal of Cereal Science, vol. 4, p. 233-239.

CHAU, C. and CHEUNG, PCK. 1999. Effects of the physicochemical properties of three legume fibres on cholesterol absorption in hamsters. Nutrition Research, vol. 19, no. 2, p. $257-265$.

CRAVEIRO, AA., CRAVEIRO, AC. and QUEIROZ, DC. 1999. Quitosana: a fibra do futuro. Fortaleza: PADETEC. 122 p.

DAVIDSON, M. and MCDONALD, A. 1998. Fibre: forms and functions. Nutrition Research, vol. 18, no. 4, p. 617-662.

DURAND, M. et al. 1997. Fermentation of green alga sea-lettuce (Ulva $s p$ ) and metabolism of its sulphate by human colonic microbiota in a semi-continuous culture system. Reproduction Nutrition Development, vol. 37, no. 3, p. 267-283.

DVIR, I. et al. 2000. Soluble polysaccharide and biomass of red microalga Porphyridium sp. alter intestinal morfology and reduce serum cholesterol in rats. British Journal of Nutrition, vol. 84, no. 4, p. 469-476.

FEMENIA, A., LEFEBVRE, AC., THEBAUDIN, JY., ROBERTSON, JA. and BOURGEOIS, CM. 1997. Physical and sensory properties of model foods supplemented with cauliflower fibre. Journal of Food Science, vol. 62, no. 4, p. 635-639.

FLEURENCE, J. 1991. L'habilitation des algues en alimentation humaine: le point sur la réglementation française. Industries Alimentaires et Agricoles, vol. 108, no. 6, p. 501-502.

FRANCO, G. 1992. Teor de fibras em alimentos. In Tabela de composição química dos alimentos. São Paulo: Atheneu. p. $177-184$

GLICKSMAN, M. 1987. Utilization of seaweed hydrocolloids in the food industry. Hydrobiologia, vol. 151-152, p. 31-47.

HOLLANDER, M. and WOLFE, D. 1999. Nonparametric statistical methods. New York: John Wiley and Sons. 787 p.

JIMENEZ-ESCRIG, AE. and SANCHEZ-MUNIZ, FG. 2000. Dietary fibre from edible seaweeds: chemical structure, physicochemical properties and effects on cholesterol metabolism. Nutrition Research, vol. 20, no. 4, p. 585-598.

JOLY, AB. 1965. Flora marinha do litoral norte do Estado de São Paulo e regiões circunvizinhas. Boletim da Faculdade de Filosofia, Ciências e Letras da Universidade de São Paulo, vol. 294 , no. 21 , p.1-393.

KATCH, FI. and MCARDLE, WD. 1993. Introduction to nutrition, exercise and health. London: Lea and Febiger. p. 63-83.

KHOKHAR, S. and KAPOOR, AC. 1990. Effect of dietary fibres on bioavailability of vitamin A and thiamine. Plant Foods for Human Nutrition, vol. 40, no. 4, p. 259-265.

LAHAYE, M. 1991. Marine Algae as source of fibres: determination of soluble and insoluble dietary contents in some "sea vegetables". Journal of the Science of Food and Agriculture, vol. 54 , no. 4, p. 587-594.

LAHAYE, M. and JEGOU, D. 1993. Chemical and physicochemical characteristics of dietary fibres from Ulva lactucca L. and Enteromorpha compressa (L) Grev. Journal of Applied Phycology, vol. 5, no. 2, p. 195-200.

LAHAYE M. and KAEFFER B. 1997. Seaweed dietary fibres: structure, physico- chemical and biological properties relevant to intestinal physiology. Science des Aliments, vol. 17, p. $563-584$

LAHAYE, M. and ROBIC, A. 2007. Structure and functional properties of ulvan, a polysaccharide from green seaweeds. Biomacromolecules, vol. 8, no. 6, p. 1765-1774.

MACPHERSON, R. 1993. Dietary fibre: a perspective. In SPILLER, GAS. (Ed.). CRC handbook of dietary fibre in human nutrition. Boca Raton: CRC Press. p. 7-11.

MAHAN, LK. and ESCOTT-STUMP, S. 1996. Krause's food nutrition and diet therapy. London: WB Saunders Company. $1194 \mathrm{p}$. 
MATZ, AS. 1996. Formulation and processing dietetic foods. Texas: Pan-Tech International. p. 136-182.

MICHEL, C. and MACFARLANE, GT. 1996. Digestive fates of soluble polysaccharides from marine macroalgae: involvement of the colonic microflora and physiological consequences for the host. Journal of Applied Bacteriology, vol. 80, no. 4, p. $349-369$

MICHEL, F., THIBAULT, JF., BARRY, JL. and BAYNAST, R. 1988. Preparation and characterization of dietary fibre from sugar-beet pulp. Journal of the Science of Food and Agriculture, vol. 43 , no. 1 , p. $77-85$.

NAUSS, JL., THOMPSON, JL. and NAGYVARY, J. 1983. The binding of micellar lipids to chitosan. Lipids, vol. 18, no. 10, p. $714-719$.

NYMAN, M. 1995. Effects of processing on dietary fibre in vegetables. European Journal of Clinical Nutrition, vol. 49, no. 3 , p. $215-218$.

OMAYE, ST., CHOW, FI. and BETSCHART, AA. 1982. In vitro interaction of $1-{ }^{14} \mathrm{C}$-ascorbic acid and $2-{ }^{14} \mathrm{C}$-thiamin with dietary fibre. Cereal Chemistry, vol. 59, no. 5, p. 440-443.

POTTY, VH. 1996. Physico-chemical aspects, physiological functions, nutritional importance and technological significance of dietary fibres - a critical appraisal. Journal of Food Science and Technology-Mysore, vol. 33, no. 1, p. 1-18.
PROSKY, L., ASP, NG., SCHWEIZER, TF., DEVRIES, JW. and FURDA, I. 1988. Determination of insoluble, soluble, and total dietary fibre in foods and food products: interlaboratory study. Journal Association off Official Analytical Chemists, vol. 71, no. 5, p. 1017-1023.

RUPÉREZ, P. and SAURA-CALIXTO, F. 2001. Dietary and physicochemical properties of edible Spanish seaweeds. European Food Research and Technolog, vol. 212, p. 349-354.

SIZER, F. and WHITNEY, E. 2007. Nutrition: concepts and controversiesi. London: Thomson Learning. 816 p.

SUZUKI, T., OHSUGI, Y., YOSHIE, Y., SHIRAI, T. and HIRANO, T. 1996. Dietary fibre content, water-holding capacity and binding capacity of seaweeds. Fish Science, vol. 62, no. 3, p. $454-461$

TAYLOR, WR. 1960. Marine algae of the eastern tropical and sub-tropical coast of the Americas. Ann Arbor: The University of Michigan Press. p. 860

WYATT, NH., GEE, JM. and JOHNSON, IT. 1988. Intestinal microflora and gastrointestinal adaptation in the rat in response to non-digestible dietary polysaccharides. British Journal of Nutrition, vol. 60, p. 197-207.

WYNNE, MJ. and BOLD, HC. 1978. Introduction to the algae structure and reproduction. New Jersey: Prentice and Hall. $706 \mathrm{p}$. 